\title{
THE REPRESENTATIONS OF HISTORIC JEDDAH
}

\author{
ROSEANN “RAZAN” TARIQ SIJEENI \\ The Graduate School of Design, Harvard University, USA \\ University of Business and Technology, Jeddah, Saudi Arabia
}

\begin{abstract}
This paper intends to address the emerging and conflicting issues of "conserving" and "representing" identities of cultural heritage in Historic Jeddah in Saudi Arabia, locally known as Al Balad. The goal is to provoke questions about what conservation represents in the context of Al Balad. It is a commentary on the way the festivals represent the culture of the place to the citizens, locals, and to the world. This project critically analyzes the different layers of realities in these representations through two mediums, the first is this text, and the second is short videos. For the purpose of grasping the complexities of representing and conserving cultural heritage, this paper defines three different notions of realities that are being addressed in Al Balad. The first is Surreality, the second is Reality and the third is Hyperreality.

Keywords: conservation, Al Balad, Historic Jeddah, representation, culture, heritage, identity, preservation, Islamic Heritage, reality, past.
\end{abstract}

\section{INTRODUCTION}

On the 38th session of World Heritage Committee in Doha, Qatar, in June 25th, 2014, Historic Jeddah was inscribed under the name Historic Jeddah, the Gate to Makkah as a World Heritage Site (WHS), worthy of UNESCO's Outstanding Universal Value (OUV). For a site to be considered by UNESCO as worthy of OUV, it must meet at least one out of ten criteria. Jeddah reflected three criteria, the first (ii): Historic Jeddah "represents" an important exchange of human values, evident in the built environment; the second (iv): the historic town is "an outstanding reflection of its final flourishing as a trading and pilgrimage city" ; and the third (vi): Jeddah is, in a tangible and intangible level, associated with the annual pilgrimage to Makkah.

This paper defines the different notions of realities that are being addressed in Al Balad, by giving each a name and a context. The first is "Surreality" which touches on the descriptions of the different globetrotters throughout the centuries, how they represented the city in their writings. In addition to the documented videos of the past, what the hyperreal attempts to revive; the utopian old days. The second is "Reality" which refers to the situation of Al Balad; what developments and conservations are taking place or have taken place, the transformation that happened and led to the representation of a hyperreal reality. Moreover, in the video segments, Reality refers to the inhabitants of the old town and their daily interactions through the lens of visitors who documented their visits in Al Balad. The Third is "Hyperreality", and it alludes to the festivals in Al Balad; this paper analyzes and criticizes the meaning of what these festivals represent, while the short video visually criticizes and compares the representations of the Hyperreality with Reality and Surreality.

\section{SURREALITY}

"Surreality" touches on the documented past, what the hyperreal attempts to revive; the utopian old days. The term surreality also refers to how the past is being re-collected; during the 20th century, most of the local Jeddawis who wrote the history of Jeddah, they wrote 
about how life used to be from their memories. Their descriptions often times, in a sense, are of a very surreal past, one that is viewed as a complete entity on its own, and not as a process that led to today.

\subsection{Jeddah: place and history}

Jeddah historically was the main port and gateway to the holy city Makkah. It is located on the west side of Saudi Arabia by the Red Sea. Jeddah's role as the gateway to the international pilgrimage site of Makkah advanced the city in social, economic and political ways. In the past century, the city was subject to major transformations as it became part of the new kingdom of Saudi Arabia, and with the discovery of oil in the 1930s, it connected to the modern world. This transformed the city rapidly; locals deserted their old houses and moved to modern ones, asphalt streets cut through the old town, redefining inner spaces, and the ancient protective wall that once surrounded Al Balad was demolished to allow further expansion of the city. All of these rapid changes led to the creation of a gap between the past and the present in the memory of the people who used to inhabit the area. In the attempts to keep Al Balad as a UNESCO World Heritage Site (WHS), it underwent processes of conservation, accompanied by a series of newly created annual festivals.

\subsubsection{Historical narratives}

To provide a historical sense of Al Balad and its dynamics I have used the most referenced encyclopedia on the city, The Encyclopedia of the history of Jeddah by the historian AbdulQudus Al Ansari [1]; he traced different travellers' accounts from their visits to Jeddah, roughly spanning the 10th century to the early 20th century. His narrative shows that the city historically has been a mixture of different cultures. Thus, I argue, it has always been a "global" city because it contained different ethnicities, religious beliefs, and cultures in its social fabric.

\subsubsection{The Port of Makkah}

Jeddah gained its significance as both the main port and the gateway to the holy city in 648 A.D, when the caliph Othman Bin Affan, the follower of Prophet Muhammad peace be upon him (PBUH), appointed Jeddah to be the storage depot for the holy city Makkah, and the main port that welcomed the pilgrims [2]. The city progressed economically as it opened its gates to the pilgrims who travelled from all over the world to the holy city during pilgrimage season. This new role also opened opportunities for trade to flourish. Thus, the birth of Islam circa $600 \mathrm{AD}$ was an essential element in keeping the heart of Jeddah beating as a center of mixed cultural commerce. Furthermore, it boosted the city socially, as a place that not only hosted Muslims from different nations, but also welcomed immigrants from non-Muslim countries because of the value of commerce at the seaport. This inflow of visitors created the need for diverse guides to holy sites, and other social jobs that required multicultural lifestyles. As a result, this mosaic of cultures based on trade and Islam opened up the social fabric of the city to accommodate the different people that poured into it [1]. In addition, the variety created by trade and being the gateway steered the city into a more politically liberated direction, as Jeddah was named Balad Al-Qanasil (The City of Consulates). For centuries, diplomats and ambassadors from around the world resided in Jeddah. Because nonMuslims are prohibited from entering the holy city Makkah, Jeddah became the regional center point for foreign affairs according to [3].

After Al Balad became the gateway to Makkah, it had fallen under different cultural and sociopolitical drifts from the 10th century to the early 20th century. Following the Caliph's 
period, in the 10th century A.D. Al Balad was described in manuscripts by three different geographers and voyagers referenced by [1]: Abu Zayd Ahmed ibn Sahl Balkhi (Afghanistan), Abu Ishaq Ibrahim ibn Muhammad al-Farisi al Istakhri (Iran), and Muhammad ibn Ahmad Shams al-Din al-Muqaddasi (Palestine); as thriving under wealthy Persian merchants, and in fact most of its residents were Persians. In addition, the city was known as Makkah's warehouse and as a place of trade with Egypt and Yemen. Further it was described physically as being surrounded by a wall that protected it, and as having beautiful yet eccentric architectural style [1]. A century after, in the 11th century A.D. another poet and philosopher, Nasir Khusraw (Iran), also referenced by [1], described the city in a similar manner, which indicated stability in the region. Khusraw estimated the number of Jeddah's population as 5000 at the time. During the 12th century A.D, a globetrotter from Al Andalus known as Ibn Jubayr described Jeddah in a completely opposite state to the previous century according to [1]. He wrote: it was a destitute place, the locals were extremely poor and desperate for food, they would do any available labor for food. He also described the built environment as though he's looking at evidence of a previous great civilization that ended, as the structures were falling apart. A century later, in the 13th century A.D. from Ibn AlMujawir manuscript Tarikh al-Mustabsir, referenced by [1], Jeddah seemed to be slightly more prosperous than before, as he described the presence of overcrowded hotels, yet he wrote that the locals, who were mostly Persians (or as he called them Ajm, means foreigners), were suffering from lack of water. As for the history of the city, Ibn Al-Mujawir recited the point when the Islamic Caliph made Jeddah the gateway, but he also recounted what the city was before; after the destruction of Siraf, a Persian city, the people migrated to Jeddah and inhabited it, then sustained it with trade. In the 14th century Jeddah suffered from another decline, according to the description of the Moroccan traveller Muhammad Ibn Battuta [4]; there was a decrease in population number, and an increase in poverty. Also, Ibn Battuta wrote that it was well known that Jeddah was built by the Persians. In the 16th century [3], worte that Jeddah came under the Mamluk Sultanate, and in this period the port gained great importance from commerce, because the Mamluks promoted its use by reducing the custom duties in Jeddah's port, while increasing them in nearby ports, which encouraged merchants to stop first at Jeddah's port over all others.

However, the Islamic World according to [1] in the 16th century was also under attack by different Western powers that wanted to control the sea trade. One famous event that is indicative of this, and mostly recited by historians, is the Portuguese early 16th century attack on Jeddah. Jeddah, at that time, was ruled by the Al-Ashraf Qansuh al-Ghauri, the second to last of the Mamluk sultans in Egypt. He protected and defended Jeddah and the two holy cities, Makkah and Al Madina. During the 17th century A.D, the power shifted from the Al Mamluks in Egypt to the Ottomans in Constantinople. This transition caused some instability in Jeddah, as it was governed by two leaders, a Turkish Wali (Governor) from Constantinople and a local citizen as vice-governor. Moreover, in the 17th century, Jar Allah Al-Qurashi AlHashimi, a historian and an imam from Makkah referenced by [5], wrote a manuscript that describes Jeddah and its importance to Makkah. He recounted the different mosques in the city, and praised an Indian merchant who renovated Al Shafie mosque, and a Persian trader who renovated another mosque. And that indicates the important role of the pilgrims in sustaining Jeddah. Al-Hashimi also mentioned the fact that Jeddah was built by the Persians and referred to the existence of archaeological evidence of Persian architecture. In addition, he described how the Persians left their houses to decay in Jeddah, and then the Bedouins took over their abandoned homes.

According to [6], in the 18th century, a manuscript by AbdulQader bin Ahmad bin Muhammad bin Faraj Al Shafie, a historian and orator, aka khateeb, from Jeddah wrote about 
the history of the city. Al Shafie referenced Al Hashimi from the 17th century, when he wrote about the Persians inhabiting the city, yet he elaborated on the cause of their abandonment; the ruler in Makkah requested higher payments "taxes" from traders after one of the wealthy merchants by mistake paid in gold instead of iron. He then concluded that after the Persians left, Bedouins and people from different places have inhabited the city, as a result, the origins of the locals come from different places such as Egypt and Yemen. Early in the 19th century, the Swiss geographer and orientalist John Lewis Burckhardt (1784-1817) [7], described Jeddah meticulously and he captured the city's social life, economic status, and political shifts from Al Sharifs, the Ottomans, and the Wahabis. The Swiss geographer described Jeddah as a modern city. He explained its importance 'as a market of Indian goods can only be traced to the beginning of the fifteenth century, although it had been known in the most ancient times of Arabian history as the harbor of Mekka.' Burckhardt also wrote about Al Balad's inhabitants; he observed that they 'may still be recognized in the features of their descendants, who are all mixed in one general mass, and live and dress in the same Arab manner. The Indians alone remain a distinct race in manners, dress, and employment.' Some of the countries [7], believed the inhabitant originated from are Hadramaut, Yemen, India, Malaysia, Indonesia, People of Maskat, Egypt, Syria, Barbarys, European Turks, and Anatolians. Burchhardt also noted that the inhabitants consider their residency as temporary, and that they are focused on trade. As for the people he considered locals, he described them as the descendants of the ancient Arabs. [7], wrote that they have perished or emigrated to other countries, and that the natives are the few families of Sharifs.

In the 19th century, another traveller from Lebanon, Butrus Al-Bustani, mentioned by [1], described Jeddah's population in his book The Encyclopedia of Arabs as a mix of different nationalities and races coming from Hejazis, Central Arabia "Najdis", Yemenis, Hadhramis, Egyptians, Syrians, Persians, Indians, Africans, Turkish, Greeks, Italians, British and French. Al-Bustani wrote that most of the immigrants came as pilgrims during Al Hajj season, then inhibited the city as they found better opportunities to make a living and form families. While others, Al Bustani said, came as traders, taking advantage of the city's location on the Red Sea and its function as a port and a point of exchange. In the early 20th century, the Emir of the holy city Makkah Al Sharif Hassan bin Ali, seized Jeddah and succeeded in taking over the town from the Ottoman empire where he ruled for 10 years. After this period, the king of Najd, Abdul-Aziz Al Saud, seized the city and he succeeded in taking over Jeddah in 1926.

\subsubsection{Characterizing the place}

The historical narrative provokes questions regarding who is considered to be native, and what defines locality in the context of Jeddah. Certainly, this paper has not looked at all of the travelers' old manuscripts and analyzed them deeply, as that would have been another type of research. But rather it used Al-Ansari's Encyclopedia of Jeddah as the main reference, because Al-Ansari summarized and interpreted the voyageurs' texts, and the intention was to give a broad historical and descriptive sense of Al Balad. Nevertheless, I have searched for each traveller's account separately; in some instances, I was able to obtain their manuscripts online or from Harvard library; others were harder to find. The reason for this research is to be sure of the travelers' descriptions of the city, to understand where they are coming from, and in addition to compare them to Al-Ansari's summary.

Many of the visitors described the population as diverse and almost all of them mentioned the role Persians played as builders who constructed Jeddah. It is worth noting in which season these travelers had visited Jeddah. Many passed by it during the annual pilgrimage season, during which time the city would have seemed very mixed. However, this paper have 
included some accounts of the travelers who were from the region or lived in the city for few years, like the Swiss Orientalist Burckhardt, and the local orator Al Shafie, both were in the same century, the 19th, and they still observed the city as multi-ethnic.

Doreen Massey [8] stated that places are always built out of social relations, and these social relations are not just local, but also connect the place to other places. 'Their (local uniqueness) is always already a product of wider contacts; the local is always already a product in part of (global) forces' [8]. Which is on point to the case of Al Balad, as a welcoming gate that functions in its connections to other distant places, this may have begun at first at a small geographical scale, but it grew vastly as different kingdoms ruled, and as the religion spread and expanded geographically. Moreover, Jeddah as the center of commerce, in the middle of the Red Sea, with maritime connections south to north and east to west. These connections have built the character of Jeddah and have shaped the cultural identity of Jeddah. "The constructions of the character of places...fails to recognize the long history of interconnectedness with elsewhere..." [8], but also assume a certain relationship between the identity of the place and its past.

\subsection{Reality}

After the country's formal declaration as the Kingdom of Saudi Arabia in 1932, and during the rule of King Abdulaziz Al Saud, oil was discovered in 1933 in the Saudi lands [9]. That discovery pushed the country into high modernity. Tracing back the first point of contact with the United States of America in the 1930s up until the 1990s provides an overview of how the country developed and modernized. The partnership between the USA and the oil company CASOC was of note; it was first operated by the Americans, and then slowly, roughly 50 years from the discovery of oil, the company became fully owned by the Saudi Government. The connections that came from oil contributed to how the society was changing, and how the urban fabric of old organic small towns expanded to accommodate new technological advancement.

\subsection{Black Gold; the ace in the hole}

In Jeddah, as the oil revenues poured in, urban development swept the city according to a study done by Abdulaziz Abu Sulaiman [10]; foreign companies such as Bechtel, WMIL (Wilson-Murrow International Limited), RMJM (Robert Mathew Johnson Marshall) and others-built roads, new suburbs, and instead of proposing continuation of old expansion patterns, the city streets and neighborhoods conceived entire independent neighborhoods that were envisioned by master plans. These plans have reconfigured spaces in Al Balad and outside of it. For example, the construction of the new sea port further offshore, which was necessary to accommodate the larger ships of the modern oil industry, separated the old town from the old port. The new port was built to transition Jeddah, and the country as a whole, toward the scale of modern ships and modern life. As Historic walls were knocked down, new town centers and new buildings in modern styles were constructed, new highways were built, and new suburbs were created that connected to the old city by automobile and truck, all in which are fuelled by oil. In addition to responding to local needs of oil, the new sea port was also constructed to accommodate and satisfy what the oil industry would bring into the country, thus easing connections to distant places. This is where the country was adapting to the modern project, by refining the physical environment, and accommodating the "universal" system of import-export. 
Another example is the execution of RMJM 1973 Master Plan that started with the construction of a more extensive transportation network in Jeddah, which would solve the issue of crowds during the pilgrimage season. There were two kinds of road network in the 1973 RMJM plan, the first: regional roads that connected Jeddah to nearby cities, especially the two holy cities; the second, the inner-city streets that connects various points within the city to one another. One of the significant roads was the outer highway surrounding the easternmost borders of Jeddah that linked the new airport built in the north to Al Madinah highway, which connected the airport to the holy cities, Makkah and Al Madina. That enabled pilgrims who fly in by airplane to travel more conveniently and directly from the airport to the holy cities, without having to pass through Al Balad.

These changes radically transformed the city and its connection to the pilgrims. When steamship ruled transportation, most pilgrims came by ship to the port and then from the port flowed out into the city where they found lodging and food. The change of scale of the port to serve the oil industry was paralleled by the new transportation system that brought most pilgrims by air to the airport - and then they could entirely avoid the old city of Jeddah, going directly to Makkah. Just as the shift from coral rock buildings to concrete undid generations of builder families, so the change in transportation undid generations of merchants, hoteliers, guides, and transport who had served the pilgrimage.

\subsection{The disembedding mechanism}

The Oil industry worked as a disembedding mechanism for spatial patterns with following effects on social relationships and shifts of power in the Saudi lands. Anthony Giddens [11], explained how Modernity lifted out social relationships from their context, he addressed social systems based on the disembedding mechanism model. I am borrowing [11], prototype to provide a different lens to look at Reality, to understand the causes that led to the current state in Al Balad, and to understand why the representations of Historic Jeddah are hyperreal.

Giddens [11], addressed the complex effects of modernity to our perception of time and space, and how it changed our awareness of our urban environment. He explained that modernity caused the "lifting out" of social interactions from their immediate context of "here and now" and reformed them across distances and time. The way I am using his model is by looking at certain events that caused the disembedding of the traditional spatial patterns that had existed for many centuries in Al Balad. These events, such as the discovery of oil, are the disembedding mechanisms, which detached traditional time from space, ruptured the urban fabric and as a result, spurred social change.

The city itself became connected to the world system because of the connections oil generated to other places, and because of the money oil generated. For instance; people in Jeddah not only consume local food, but they also eat food that comes from other places, possibly places they have never been to. And they eat food that was prepared by people they might never meet or see. And this is how the formerly premodern interactions between people have been left out of the context of Jeddah and connected to distant places. Yet, people in Jeddah and in Saudi Arabia have modified their traditional practices and preserved their religious application in the modern and the premodern eras. For example, people go to mosque every Friday, the call for the five prayers (Adan/Azan) five times a day takes place every day still, and both of these practices have been happening since the birth of Islam. However, the use of loudspeakers and microphones in mosques, the addition of electricity and then air conditioning inside the mosques, even the architecture of the mosques, have all changed. Another example, the pilgrims go to Makkah every year, that practice in itself has not changed, but the road to Makkah and how they used to go there have been transformed. 
Where in the past they used domestic animals, or walked on their feet, or useed ships and small boats, today they go to the pilgrimage using airplanes and automobiles. They have not preserved the old way of taking the journey to the holy cities but modified it. Those practices are communal, not individual choices, they in a way, represent the modernising values of the community as a whole.

In Jeddah, modernity has drastically affected the built environment, sweeping across the old urban fabric, impacting the old houses, where it physically transformed the place. Modernity disregarded the history of the city's organ/body/structure/, it ruptured the continuity of history in the built environment. As a result of this rupture, social practices have been forced to adapt to modernity. As Harvey [12], stated in his book The Condition of Postmodernity, any meaning for history today, in this case the history of Jeddah's architecture and how it developed, and the history of traditional practices, had to be discovered and defined amidst the swirl of change, perhaps even being totally reconstructed, turning the representations of the inherited traditions to be Hyperreal.

\section{HYPERREALITY}

"Hyperreality" refers to the festivals in Al Balad; what the tourists experience in the temporary fairs. The representations during the festivals are hyperreal because they take certain, "beautified" moments of the past, and present it as the whole truth.

Before the designation by UNESCO in 2014, and since 2012, Al Balad became an attraction locally and internationally. There are two festivals that take place annually, one during the holy month of Ramadan, and the second one is during spring break. Every year, these festivals upgrade their activities to include different themes and representations of the old town. These festivals have been successful in attracting visitors, and every year the number of visitors increase, making it one of the biggest festivals in the Saudi kingdom. The activities in the festivals, beyond the sightseeing of the old cultural architecture, range from plays that capture the life in the past filled with nostalgia and longing, folklore song performances, small shops that sell traditional and non-traditional food, souvenirs and gift shops, to individuals taking play-role representation, for instance the milkman, in the alleys of the historic town, or children mimicking the children of the past playing traditional games in the plazas.

\subsection{Authenticity}

I would like to draw a comparison between the notion of what is authenticity in Jeddah's festivals and two sources: the first [13], is Authenticity: What Consumers Really Want, and the second [14], is Staged Authenticity: Arrangements of Social Space in Tourist Settings. The first source [13], has developed a business model of how to achieve authenticity to improve sales, and the second source [14], shows how tourists behave in historic sites in order to experience "intimate authenticity". When personal tours started in Jeddah, they were conveying an "authentic" experience as described by [13], "Experiences are memorable events that engage individuals in an inherently personal way". These tours worked like a time machine, giving visitors a sense and experience of an imaginative lifestyle they know can never happen again, a peek into the simple life of the utopian past, which leaves them with thoughts about wanting to experience it even more, because the past is "forever gone ... the past represents an ideal form of authentic experience - the pure"[13]. [14], makes a point that tourist settings are organized to create stages of front and back areas to support the idea of authenticity. The festivals that happened in Al Balad, for instance, consisted of the backstage; the organizers who staged the place, and the actors who re-enacted the traditional roles. 
The front stage is the audience, the tourists, and how they experienced "authenticity". He [14], also describes acts of sightseeing as a "ritual respect for society and tourism absorbs some of the social functions of religion in the modern world". His description might shed light on the behaviour of foreign tourists in Jeddah who experienced an "authentic" moment in observing traditional inherited activities like the call for prayers which locals normally do ([15], Video). The call for prayers from an 800-year-old mosque makes the visitors feel that they are living an authentic experience. However, the local perception of such experience is no different than praying in a modern mosque in terms of authenticity.

\subsection{Representations}

When looking at Historic Jeddah's representation today, it always falls within the spectrum of the best of the past, or the pasts that never were. That is, for instance, in terms of the physical aspect, what the exterior of Al Balad's architecture represents and the social function the ancient wooden windows (Rwasheen) holds; where they were used for privacy concealing the interior while allowing cool air into the house. Also, how the traditional materials responded to the weather and were suited to the local environment, indeed how the urban fabric was fit for the climate, where the narrow alleys between buildings create shades which cools down the temperature for the passers-by and in terms of culture, it expresses how society loved one another, and cared for one another; how there was no hatred, grudge, selfishness; no starvation, poverty, dehydration, or illness. Indeed, it is the memory of a Utopia. That is what the festivals are representing. The representation fails to understand the language of the structure its representing; it fails to analyse the typology of the architecture, it fails to reflect the values of the cultural practices beyond attracting tourists, it fails to teach the present generation the values their ancestors had; their openness and inclusiveness of the different cultures that were immersed within the urban fabric and were evident in the structure of the architecture.

The representations in the festivals do not reflect a specific ideology, but rather they reconstruct an identity from a reinterpreted past, a utopian reminiscence that feeds from and into the nostalgic present - a present that is perceived as a separate spectrum from the past. Not only the representations are hyperreal; but they also conceal the "reality." They represent a touristic identity. The larger issue is in how the Jeddawis (citizens who used to live in AL Balad) are claiming that they are creating an authentic identity; embracing that identity as a utopian vision to the extent that they are considering the existence of local residents as the cause for the deterioration of the built environment which then is seen as a misrepresentation of the greatness of the history of that town. In creating their utopian authentic vision of the old town, the Jeddawis and the festivals overlooked the many years of the inhabitants in $\mathrm{Al}$ Balad, as well their cultural values.

Jeddah was and is a global city, as a center of trade and a great religious experience. It has been the role of its inhabitants to keep the cosmopolitan society ongoing. What I argue needs to be critically conserved is beyond the old fabric and built environment, but rather the tolerance of differences, the interdependence of individuals on each other; a conservation of the values and morals that made and constructed the city global. These values produced the historical buildings that are being praised. Did the function of the port and gateway shape Jeddah, or did Jeddah shape that function? In today's representations as a tourist center, the latter seems to be the answer. 


\section{CONCLUSION}

Starting with Surreality, the literature represents Al Balad from different perspectives and accounts, which leads to a sense of its dynamic throughout the history. Following that point comes Reality, which signifies the wave of modernity that was triggered by the discovery of Oil, which in turn provides one explanation for the present state of Al Balad in normal days, inhabited mostly by poor, low-wage workers, and all the developments that led to the current reality. Finally, finishing with the an analysis of the Hyperreal shed light on the consequences of modernity and Reality, which creates a separate past that is ready to be captured and represented. As a result, the festivals today presents the new generation with a sense of nostalgia and a look into a perfect past, as it feeds from the romantic memories of the past generations that lived in Al Balad.

The intended contribution of this project is in being provocative to trigger both thought and action. It is in the lens I am providing to see the complexity of a place like Jeddah, and to understand what conservation is representing, and how the citizens experience these representations. In reconstructing a different dimension of reality, I conclude with a lens that I hope captures a distorted, fragmented representation of Al Balad in the video [16]. I am reconstructing the meaning of the architecture as a language that represents culture by overlapping its structure with its old self, by overlapping the pilgrims of the past with the tourists and visitors of today, in both reality and hyperreality [16].

\section{ACKNOWLEDGEMENTS}

To my Father, Dr. Tariq Sijeeni, my mother, Abeer Sajini, and my siblings, Salem, Ziad and Mona; Thank you for your constant support. To my Professors, George Thomas and Susan Snyder, I am grateful for your guidance. To Aseel Bashraheel, for your kind support and constant encouragement. Finally, to your soul, Edward Said, may you rest in peace.

\section{REFERENCES}

[1] Al Ansari, A., The Encyclopedia of the City of Jeddah's History. 3rd ed. Cairo, Egypt: Dar Misr For Printing; 1982.

[2] Al Mana'a, A., The History of the Non-Historical: Jeddah: The Human and The Place. King Fahad National Library and References, 2011.

[3] Diyab, M., Jiddah: al-tārīkh wa-al-hayāh al-ijtimā'īyah (Jeddah; the history and social life), King Fahad National Library Index, 2002.

[4] Battuta, I., Tuhfat al-nuzzāar fī gharā ib al-amșār wa 'ajā ib al-asfār (The Precious Gift for Those Who Would Look into the Wonders of Cities and the Marvels of Travel), 1355.

[5] Ali, Q.H.H., The Grace of Jeddah and its closeness to Makkah; Jar Allah Al-Qurashi Al-Hashimi 954 H, King Fahad National Library and References, 2012.

[6] Omar, A.M., The History of Jeddah by Abdul Qader bin Ahmad bin Muhammad bin Faraj Al Shafie, (n/a).

[7] Burckhardt J.L., Travels in Arabia, comprehending an account of those territories in Hedjaz which the Mohammedans regard as sacred. By the late John Lewis Burckhardt. Published by authority of the Association for Promoting the Discovery of the Interior of Africa, London: Henry Colburn, 1829.

[8] Massey, D. \& Jess, P.M., A Place in the World? Places, Cultures and Globalization, Oxford: Oxford University Press, 1995.

[9] Facey, W. \& Grant, G., Saudi Arabia: By the First Photographers, London: Stacey International, 1996. 
[10] Sulaiman, A., \& Mahdi, A., Learning to Plan, Jeddah (1959-1987), Philadelphia, PA: University of Pennsylvania, ProQuest Dissertations Publishing, 1996.

[11] Giddens, A., The Consequences of Modernity, Stanford: Stanford University Press, 1990.

[12] Harvey, D., The Condition of Postmodernity: An Enquiry into the Origins of Cultural Change, Oxford: Basil Blackwell, 1989.

[13] Pine J. \& Gilmore, J.H., Authenticity; What Consumers Really Want? Cambridge, MA: Harvard Business School Press, p. 40, 2007.

[14] MacCannell, D., Staged Authenticity, Chicago: University of Chicago Press, JSTOR PDF e-book, P590, 1973.

[15] ALWADOUD1. "Reporter Crying After Hearing the Adhan". www.youtube.com/ watch?v=Wbh-S5uq8SY. Youtube video, 01:58. Accessed on: 13 Apr. 2016.

[16] Sijeeni, Roseann., Representations of Historic Jeddah: Segments. fragments. layers. https://vimeo.com/250309414. Vimeo video, 05:53. 